\title{
The Repatriation Debate after the Abolition of INDENTURE
}

\section{Heena Mistry}

Wilfrid Laurier University

\begin{abstract}
While campaigning for the abolition of indenture, Indian elites encouraged indentured Indians and their descendants to repatriate to India to contain the dispersion of Indian unskilled labourers. After the abolition of indenture in 1917, the repatriation of ex-indentured communities became a source of contention between Indians globally, as many repatriates faced marginalization and ostracization within India. Some, such as M.K. Gandhi and Charles Freer Andrews, revised their position from promoting repatriation as a strategy for containing the tragedies of indenture, to arguing that Indian national liberation from empire would better position an independent Indian state to negotiate on behalf of Indians abroad. Others, such as ocean-crossing activist, Bhawani Dayal Sannyasi, and journalist, Benarsidas Chaturvedi, argued that blanket calls for repatriation ignored the needs of repatriates and left Indians in British colonies who chose not to make a life in India at the height of the Indian anticolonial nationalist movement. These diverse and conflicting perspectives surrounding repatriation shed light on the global Indian diaspora in the context of late colonial India.
\end{abstract}

\section{INTRODUCTION}

Nearly 15 years after Indian indenture was banned, Bhawani Dayal Sannyasi, the son of two Indians indentured on Natal sugar estates - and a repatriate from South Africa himself - published a report on the hardships of Indian repatriates with Benarsidas Chaturvedi. ${ }^{1}$

\footnotetext{
${ }^{1}$ Bhawani Dayal Sannyasi and Benarsidas Chaturvedi, A Report on the Emigrants Repatriated to India under the Assisted Emigration Scheme from South Africa and on the Problem of Returned Emigrants from All Colonies (Bihar: PravasiBhawan, 1931); Prem Narain Agrawal, Bhawani Dayal Sannyasi: A public worker of South Africa (Ajitmal, Etawah (UP):
} 
Chaturvedi helped one of the most famous indentured repatriates, Totaram Sanadhya, to publish his memoires of indenture in Fiji. ${ }^{2}$ Their report called for the cessation of all Indian repatriation, and specifically criticized incentivized repatriation programs coordinated by both the Governments of India and the Union of South Africa. In the report's introduction, Chaturvedi acknowledged his own changing opinion over the Assisted Emigration scheme. Although his earlier work campaigned for the repatriation of indentured workers, he had mistakenly thought that "Colonial Born Indians could be happily settled in India." Now, he was sure that they were better off in the colonies where they had spent most of their lives. ${ }^{3}$ Sannyasi and Chaturvedi's report presented organized repatriation efforts after the abolition of indenture as a disaster that left repatriates stranded and misplaced in India, a place they had little connection to and in which they had trouble building stable new lives.

John Kelly and Martha Kaplan argue that Sannyasi and Chaturvedi's fiery report condemning repatriation schemes, which were implemented without consultation with repatriates themselves, did not speak for all repatriates. They especially question Sannyasi's condemnation of all forms of repatriation, arguing that many indentured repatriates saved up extensive remittances and invested in property upon their return to India. ${ }^{4}$ Although they capture how decolonization impacted Indians overseas, they miss the opportunity to look beyond Sannyasi and Chaturvedi's text to better understand the specific moment in the immediate aftermath of indenture, the pair operated in. While the circulation of newspapers like Indian Opinion fostered a global Indian consciousness and raised an awareness between territorial India and the local struggles of the Indian diaspora globally, the question of what responsibilities Indians overseas and territorial India had to each other remained ambiguous. ${ }^{5}$

As a form of activist literature, Sannyasi and Chaturvedi's report is written forcefully and authoritatively. This is largely because the positions it held had been dismissed, overlooked, or blatantly ignored in official circles. It rigorously outlined how the effects of organized incentivized repatriation programs, including the Assisted

The Indian Colonial Association, 1939); Bhawani Dayal Sannyasi, The Autobiography of an Immigrant (Gurgaon: Hope India Publications, 2013).

${ }^{2}$ Totaram Sanadhya, My Twenty-One Years in the Fiji Islands and The Story of the Haunted Line, trans. and eds. John Dunham Kelly and Uttra Kumari Singh (Suva: The Fiji Museum, 1991).

${ }^{3}$ Sannyasi and Chaturvedi, Report on the Emigrants, 10.

${ }^{4}$ John D. Kelly and Martha Kaplan, "Diaspora and Swaraj, Swaraj and diaspora," in From the Colonial to the Postcolonial. India and Pakistan in transition, eds. Dipesh Chakrabarty, Rochona Majumdar, and Andrew Sartori (Oxford: Oxford University Press, 2007), 311-31.

${ }^{5}$ Isabel Hofmeyr, Gandhi's Printing Press. Experiments in slow reading (Cambridge, MA: Harvard University Press, 2013). 
Emigration Scheme, further marginalized Indians overseas. It quoted from interviews with repatriates themselves and contained photographs of the Natal House in Madras, which the Government of India opened to shelter repatriates arriving under the Assisted Emigration Scheme. ${ }^{6}$ The report provides insight into the different figures who were upheld as authorities on Indians overseas or dismissed, corrected, and challenged.

Debates about the merits of repatriation both reflect the malleability of borders and add to our understanding of diaspora of and nationalism in the context of late colonial rule. In the decades following the First World War, these debates shed light on the impact of late colonial rule and the global Indian diaspora on each other. Typically defined as the decades spanning the end of the First World War to decolonization in the 1940s, "late colonial India" represents a period in which the colonial state demonstrated some degree of cooperativeness with non-state expertise and entities. Late colonial rule oversaw the liberalisation of empire and the extension of some powers of governance to colonial subjects. It was a moment characterized by the contingency of both the colonial state's continuance and the postcolonial nation-state's emergence, when colonial rule highlighted its ethical registers, and colonial subjects deliberately developed their own bilateral internationalist relations. ${ }^{7}$ Benjamin Zachariah frames late colonial India as a period in which colonial authorities declared that the end was nigh for colonialism, entailing a "gradual and orderly withdrawal" with the continuance of the imperial connection that would continue to bring important economic benefits to the metropolis. Zachariah describes a belief in the need to build a greater sense of national solidarity through determining "legitimate national aspirations" to qualify for and prepare for imminent selfgovernment. ${ }^{8}$ Complicating this gradual withdrawal was the struggle between Indian and British officials within the Government of India and diverse expressions of Indian national consciousness. Calls for and denouncements of repatriation complicated understandings of "legitimate national aspirations," as they challenged the notion that all Indians inherently belonged within territorial India. As is the case with any diasporic subjectivity or nationalist consciousness, the development of Indian nationalist and diasporic

\footnotetext{
${ }^{6}$ Sannyasi and Chaturvedi, Report on the Emigrants.

${ }^{7}$ Ritu Birla, Stages of Capital: Law, culture, and market governance in late colonial India (Durham: Duke University Press, 2009); Mrinalini Sinha, Specters of Mother India. The global restructuring of an Empire (Durham: Duke University Press, 2006); Mrinalini Sinha, "Refashioning Mother India: Feminism and nationalism in late-colonial India," Feminist Studies, 26, 3 (2000), 523-644; Antoinette Burton, Dwelling in the Archives: Women, writing house, home, and history in late colonial India (Oxford: Oxford University Press, 2003); Stephen Legg, Prostitution at the Ends of Empire: Scale, governmentalities, and interwar India (Durham: Duke University Press, 2014), 11.

${ }^{8}$ Benjamin Zachariah, "British and Indian ideas of 'development': Decoding political conventions in the late colonial state," Itinerario, 23, 3-4 (1999), 162-209.
} 
consciousness must be understood within its historically specific formations. Diaspora itself is a project that is "a matter of choice, willingness, and enterprise." Disparate sustenance of reciprocal relations between homeland and diaspora contributed to disparate outcomes in diaspora formation. ${ }^{9}$ Chaturvedi and Sannyasi engaged with these disparate understandings of diasporic belonging in India which both the late colonial state, some Indian nationalists, and white settler states each mobilized for their own purposes.

After the abolition of Indian indenture in 1917 and the First World War in 1918, repatriation arose as a remedy to the stigma of indenture in conversations led by Indians employed by the Raj and who sat in its Legislative Assemblies. The Government of India, with the support of Indian liberal bureaucrats employed in the Raj, collaborated with white settler governments to formulate programs enabling repatriation, even as these same programs undermined Indian claims to reside in white settler colonies as British subjects. Efforts by the Government of India and various colonial governments to manage local populations of Indians and their descendants in the 1920s and 1930s were inseparable from both the abolition of indenture and post-First World War developments in the relationship between India and the white settler Dominions, and British plantation colonies. Major figures who came to serve as authoritative sources and advisors on Indians overseas in the early twentieth century, such as Charles Freer Andrews, M. K. Gandhi, Bhawani Dayal Sannyasi, and Benarsidas Chaturvedi disagreed on whether repatriation could resolve the question of the precarity of Indian domicile within empire, and on whether it provided any sort of relief for Indians who, due to legal and economic forms of exclusion, could no longer afford to live in colonies outside of a labour contract.

Repatriation and other forms of deportation were administrative mechanisms that allowed colonial administrators to shape how populations were distributed across the British empire. While repatriation schemes appeared to be consensual, critics likened them to expulsion and deportation. ${ }^{10}$ In her study on the deportation of British-born migrants to Australia and South Africa from mental hospitals, Jean Smith argues that the settler colonial state aimed to socially engineer its population by excluding those it perceived to be racially "other," as well as white settlers it judged to be "racially unfit." Imperial border-management bureaucracies were eugenic projects driven by both white supremacy

\footnotetext{
${ }^{9}$ Amitava Chowdhury, "Narratives of home: Diaspora formations among Indian indentured labourers," in Between Dispersion and Belonging: Global approaches to diaspora in practice, eds. Donald Akenson and Amitava Chowdhury (Kingston: McGill-Queen's University Press, 2016), 240-53. See also: Amitava Chowdhury, "Exploring an 'old verbal ambiguity': East Indian ethnicity and identity in Trinidad and the British Caribbean," Canadian Journal of Latin American and Caribbean Studies, 37, 73 (2012), 209-20.

${ }^{10}$ Collected Works of Mahatma Gandhi (hereafter: CWMG) Volume X, 25 Apr. 1910, "Letter to G.K. Gokhale," 229.
} 
and ableism, constantly managing those deemed "undesirable" for imperial citizenship as it attempted to map racial geographies of empire. ${ }^{11}$ Other forms of social engineering include the long histories of punitive relocation within empire and its centrality to imperial expansion and management. ${ }^{12}$

The first part of this article follows conversations in the Indian Legislative Assembly between white and Indian members after the abolition of indenture. Within India, those who adhered to the "Moderate" faction of the Indian National Congress, many of whom continued to sit at the Raj's decision-making tables throughout the interwar decades, debated what to do about the dispersion of Indian labourers. Legislation they had a hand in creating veered towards containing Indian labour migration to that which circulated around the Indian Ocean world. The second part of this article follows disagreements between four vocal authorities on Indians overseas. Although more established voices, such as those of M. K. Gandhi and Charles Freer Andrews, had argued for repatriation as the most desirable alternative to remaining in places with anti-Indian legislation, less established voices raised alarm early on about any form of organized repatriation effort targeted at Indians overseas, especially those not born in India. I argue that discussions about repatriation and the containment of globally dispersed Indians and their descendants reveal tensions surrounding who defined what was in the best interests of the global Indian diaspora, and what responsibilities the Government of India had towards Indians and people of Indian descent settled in British colonies. Furthermore, the debates reveal how different voices were centered or ignored when it came to shaping policies, programming, and outreach between the Government of India and Indians overseas.

\section{REPATRIATION IN THE AFTERMATH OF INDENTURE}

Discussions between Indians employed in the British Raj and the Legislative Assembly surrounding the management of global Indian labour migration accompanied the passing of the Indian Emigration Act of 1922, and the formation of repatriation policies in the

\footnotetext{
11 Jean P. Smith, "From promising settler to undesirable immigrant: The deportation of British-born migrants from mental hospitals in interwar Australia and South Africa," The Journal of Imperial and Commonwealth History, 46, 3 (2018), 50223. Uma Dhupelia-Mesthrie, "Betwixt the oceans: The chief immigration office in Cape Town, Clarence Wilfrid Cousins (1905-1915)," Journal of Southern African Studies, 42, 3 (2016), 463-81; William Walters, "Deportation, expulsion, and the international police of aliens," Citizenship Studies, 6, 3 (2002), 276.

${ }^{12}$ Christian G. De Vito, Clare Anderson, and Ulbe Bosma, "Transportation, deportation and exile: Perspectives from the colonies in the nineteenth and twentieth centuries," International Review of Social History, 63, 26 (2018), 1-24.
} 
Union of South Africa from 1895 to the 1930s. They capture how the relationship between globally dispersed labourers and non-indentured migration featured in conversations about India's global diaspora after 1917. Public opinion in British India and among its diaspora was ambivalent about the presence of "coolies" in areas not contiguous to the Indian subcontinent. Indians in the decision-making chambers of the Raj saw the dispersion of Indian manual labourers overseas as undermining post-war efforts for India's inclusion within the white settler commonwealth and Dominion status. Towards the end of the 1920s, Indian bureaucrats in the Raj increasingly came to believe that the right of all Indians, including Indian labourers, to settle across the British empire would only be possible if the mobility and domicile rights extended to white British subjects were extended to Indians. ${ }^{13}$ Furthermore, they realized that this would only happen if British India could be made a self-governing Dominion.

Repatriation carried complex meanings in the context of indenture and other forms of Indian labour migration. The history of repatriation within the broader context of global Indian diaspora history challenges the assumption of any natural attachment to place of origin or "homeland," as well as the logics of diaspora as dispersion and diasporic belonging as inherent. ${ }^{14}$ Repatriation was a necessity to indenture that distanced it from slavery, and it was one of the mechanisms allowing the continuation of an organized and constant flow of emigrants to plantation colonies. It was and continues to be a technology that provided for the regulation of migration in the colonial genealogy of statecraft that arose in the early twentieth century. ${ }^{15}$ The repatriation debates provide a window into how colonial subjects and racialized migrants talked back against these technologies of statecraft and migration. However, the obligations of planters and colonial governments to provide repatriation, and the terms under which it was provided, shifted over time. Throughout the existence of Indian indenture, the Government of India pushed for the guarantee of free return passages to emigrants. Planters often avoided honouring this

\footnotetext{
${ }^{13}$ Sukanya Banerjee, Becoming Imperial Citizens. Indians in the late Victorian empire (Durham: Duke University Press, 2010); Radhika Mongia, Indian Migration and Empire: A colonial genealogy of the modern state (Durham: Duke University Press, 2018); Isabel Hofmeyr, "Seeking empire finding nation: Gandhi and Indianness in South Africa," in Routledge Handbook of the South Asian Diaspora, eds. Joya Chatterji and David Washbrook (New York: Routledge, 2013), 153-65.

${ }^{14}$ Prabhu Mohapatra, "Longing and belonging: The dilemma of return among Indian immigrants in the West Indies 18501950," Centre for Contemporary Studies, Nehru Memorial Museum and Library (1998), 1-61; Nalini Mohabir, "Port of departure, port of return: Mapping indentured returns to Calcutta," Small Axe: A journal of criticism, 18, 2 (2014). 108-22.

15 Radhika Mongia's book, Indian Migration in the Empire, discusses the centrality of the regulation of migration to the colonial genealogies of statecraft that arose in the early twentieth century. Mongia's work responds to scholarship like John Torpey's Invention of the Passport by noting how Torpey and others fail to account for how borders and passports in metropole and colony are co-produced, not diffused out. See: John Torpey, Invention of the Passport (Cambridge: Cambridge University Press, 2009).
} 
component of the indenture contract or offered alternatives to repatriation. ${ }^{16}$ White settler colonies attempted to manage the movement of Indian labourers from the late nineteenth century onwards. ${ }^{17}$ In South Africa, this took shape through taxes on Indians residing outside of an indenture contract from 1895 to $1914 .{ }^{18}$ In 1914, the Indian Relief Act replaced these measures with the provision of a free passage to India for non-indentured Indians, provided they give up their rights to domicile and re-entry. Gandhi, who negotiated the Indian Relief Act, agreed to these terms, which he referred to as "voluntary repatriation," because he believed that the treatment of Indians in the Union would improve if white fears of Indian encroachment into white settler spaces and population growth were assuaged. ${ }^{19}$

A set of legal mechanisms, which ensured repatriation and prevented unskilled labour emigration, slowly followed the official cessation of indenture in 1917. During the First World War, the supply of labour to sugar-producing British colonies reliant on labour from India was suspended. Historian Radhika Singha notes that in March 1917, the Government of India passed a Defence of India Ordinance that exempted the "minimum requirements" needed to maintain the circulation of labourers to Ceylon and the Federated Malay States. The presence of Indian labourers in these colonies was essential to the production of plantation crops, rubber, petroleum, and tin, and to the maintenance of dock and transport infrastructures in the Indian Ocean. Furthermore, Singha argues that although many scholars ascribe the suspension of indenture in March 1917 to the need to divert migrant Indian labour to military channels, the Government of India leveraged the military demand for Indian labour in order to suspend indentured migration entirely,

\footnotetext{
${ }^{16}$ Mohapatra, "Longing and belonging," 1-61; Basdeo Mangru, "Abolishing the return passage entitlement under indenture: Guianese planter pressure and Indian government response, 1838-1917," Caribbean Quarterly, 32, 3/4 (1986), 1-13; Hugh Tinker, A New System of Slavery: The export of Indian labour overseas 1830-1920 (London: Published for the Institute of Race Relations by Oxford University Press, 1974); Lomarsh Roopnarine, "The repatriation, readjustment, and second-term migration of ex-Indentured Indian labourers from British Guiana and Trinidad to India, 1838-1955," New West Indian Guide, 83, 1 \& 2 (2009), 71-97.

${ }^{17}$ Marilyn Lake and Henry Reynolds, Drawing the Global Colour Line. White men's countries and the international challenge of racial equality (Cambridge, UK: Cambridge University Press, 2008); Adam M. McKeown, Melancholy Order: Asian Migration and the Globalization of Borders (New York: Columbia University Press, 2008); Mongia, Indian Migration and Empire; David C. Atkinson, The Burden of White Supremacy. Containing Asian migration in the British empire and the United States (Chapel Hill: University of North Carolina Press, 2016).

${ }^{18}$ Ramchandra Guha, Gandhi before India (London: Allen Lane, 2013); Surendra Bhana, Gandhi's Legacy: The Natal Indian Congress, 1894-1994 (Pietermaritzburg: University of Natal Press, 1997); Ashwin Desai and Goolam Vahed, Inside Indenture: A South African story, 1860-1914 (Cape Town: HSRC Press, 2010).

${ }^{19}$ Uma Mesthrie, "Reducing the Indian population to a 'manageable compass': A study of the South African Assisted Emigration Scheme of 1927," Natalia, 15 (1985), 36-56; Bridglal Pachai, The International Aspects of the South African Indian Question: 1860-1971 (Cape Town: C. Struik Pty., Ltd., 1971), 73; Hofmeyr, "Seeking empire finding nation," 15365; Bhana, Gandhi's Legacy, 18.
} 
instead of reforming and continuing it, as the Colonial Office would have preferred. ${ }^{20}$ This suspension followed a long campaign of mobilization against indenture which began in the early 1830s, culminating in an organized campaign during first decade of the twentieth century. ${ }^{21}$

After 1917, the Government of India introduced legislation that ensured that timeexpired indentured Indians returned, while preventing the further emigration of Indian labourers in the face of planter attempts to renew labour migration to keep wages depressed. Some Indian elites feared that the inability of Indian labourers to return risked rendering Indians as a "servile coolie race" that could never obtain citizenship parity with white British subjects. ${ }^{22}$ In 1921, Sir George Stapylton Barnes introduced the Indian Emigration Bill to the Indian Legislative Assembly. During the war, Barnes was Commerce Member of the Viceroy's Executive Council and served on the Royal Commission on Sugar Supplies. This work consisted of expanding India's industrial capacity to meet allied war demands. ${ }^{23}$ The Indian Emigration Bill was meant to lay the "dead indentured system" in its grave. ${ }^{24}$ It stipulated the conditions under which Indians could emigrate, with measures such as the appointment of Protectors of Immigrants or Agents of the Government of India in areas where Indians settled; the mandatory inclusion of return passages for emigrants; and the prohibition of all emigration for the purpose of undertaking unskilled work without formal exemption by the legislature, except in Ceylon, the Federated Malay States, and the Straits Settlement territories. ${ }^{25}$

\footnotetext{
${ }^{20}$ Radhika Singha, The Coolie's Great War: Indian labour in a global conflict, 1914-1921 (London: Hurst \& Company, 2021), 114-16. Singha refers to the following article by Goolam Vahed in reference to this scholarship: "End of a dehumanising system," The Mercury (20 Apr. 2017): http://www.pressreader.com.libproxy.wlu.ca/south-africa/themercury/20170420/281724089428371 [Accessed: 16 Aug. 2021]. However, the following works make similar claims: Basdeo Mangru, Indenture and Abolition: Sacrifice and survival on the Guyanese sugar plantations (Toronto: TSAR Publications, 1993); Clem Seecharan, Mother India's Shadow Over El Dorado: Indo-Guyanese politics and identity, 1890s1930s (Kingston: Ian Randle Publishers, 2011). For more on Indian labour during the First World War, see: Radhika Singha, "The short career of the Indian Labour Corps in France, 1917-1919," International Labour and Working-Class History, 87 (2015): 27-62; Singha, "Finding labour from India for the war in Iraq: The jail porter and labor corps, 19161920," Comparative Studies in Society and History, 49, 2 (2007), 412-45.

${ }^{21}$ Ashutosh Kumar, Coolies of the Empire. Indentured Indians in the sugar colonies, 1830-1920 (Cambridge: Cambridge University Press, 2017), 205-40; Mrinalini Sinha, "Premonitions of the past," Journal of Asian Studies, 74, 4 (2015), 830-1.

${ }^{22}$ Kelly and Kaplan, "Diaspora and Swaraj," 314.

23 "Obituary: Sir George Barnes. Service in India and Whitehall." The Times (11 Dec. 1946).

${ }^{24}$ Lalubhai Samaldas, Extract from the Council of State Debates (CSD), 893, 23 Feb. 1922, India Office Records (hereafter: IOR): L/PJ/6/1744 File 2396; C.A. Innes, "Statement of objects and reasons," draft of the Indian Emigration Bill, 14 Mar. 1921 and Sir George Barnes in "Extract from the Indian Legislative Assembly Debates" (Henceforth ILAD), Vol. I, No. 13, 21 Mar. 1921, IOR: L/E/7/1212 File 655.

${ }^{25}$ Department of Revenue and Agriculture. Notification. Emigration, 8, 10 Mar. 1923, IOR: L/3/7/1212 file 655. See also: Sinha, "Premonitions of the past," 831.
} 
Barnes framed the Bill's restrictions as a step towards Indian self-government within the British empire. By regulating emigration from India and only allowing the unrestricted emigration of Indians with "a certain amount of intelligence, money, and enterprise," he hoped the Bill would ensure Indians were treated as whites in the Dominions were. ${ }^{26}$ A few years earlier, the Government of India Act of 1919 incrementally expanded Indian control over domestic affairs through the inclusion of Indian ministers within the provincial legislature, while maintaining foreign affairs firmly within the hands of the Raj. Indian liberals, who deplored secession from empire and criticised Gandhi, saw its reforms in conjunction with the management of globally dispersed Indian labour migration as moving India closer towards Dominion status. ${ }^{27}$

The Indian Emigration Bill contained Indian labourers and reshaped India's global image away from that of a labour reserve. It paternalistically presumed that emigrant labourers were incapable of making informed decisions about their own mobility and its effect on the perception of non-labouring Indian emigrants. Barnes declared that uncontained and unmanaged labour emigration would lead "people who had no knowledge of India" to think that indentured Indians and their descendants were "a fair sample of the Indian people." He assured that if Indian emigration policy was put on "sound lines," it would elevate Indians "in every part of the world." ${ }^{28}$ Indian proponents of the Bill shared Barnes" view, referring to emigrants as "ignorant workmen and ignorant rustics" in need of safeguards, and "persons of weak intellect" who heedlessly compromised India's "self-respect" when they went abroad. ${ }^{29}$ Moderate members of the Indian National Congress, like Gopal Krishna Gokhale and Madan Mohan Malaviya, mobilized this assumption earlier when speaking against indenture in the Legislative Council in the years leading up to indenture's abolition. ${ }^{30}$

Some members of the Legislative Assembly and Council of State worried that, in an effort to protect Indian emigrants, the Bill unnecessarily criminalized those who tried

\footnotetext{
${ }^{26}$ George Barnes in ILAD Vol I, No. 13, 3, 21 Mar. 1921, IOR: L/PJ/6/1744 file 2396.

${ }^{27}$ Vineet Thakur, "Liberal, liminal and lost: India's first diplomats and the narrative of foreign policy," The Journal of Imperial and Commonwealth History, 45, 2 (2017), 232-58; Vineet Thakur and Sasikumar S. Sundaram, "India, South Africa and the Cape Town Agreement: A diplomatic history," Indian Politics and Policy, 2, 2 (n.d.): 3-25.

${ }^{28}$ Sir George Barnes in Extract from ILAD, Vol I, No. 13, Mar. 21, 1921, IOR: L/E/7/1212 file 655.

${ }^{29}$ BN Sarma, Extract from CSD, 891, 23 Feb. 1922, IOR: L/PJ/6/1744 file 2396; Pyari Lal, Excerpt from ILAD, 2192,6 Feb. 1922, IOR/L/PJ/6/1744 file 2396.

${ }^{30}$ Madhavi Kale, Fragments of Empire: Capital, slavery, and Indian indentured labour migration to the British Caribbean (Philadelphia: University of Pennsylvania Press, 1998), 155-71. See also: Radhika Singha, "The Great War and a 'proper' passport for the colony: Border-crossing in British India, c.1882-1922," Indian Economic and Social History Review, 50, 3 (2013), 289-315;. Kelly and Kaplan, "Diaspora and Swaraj,” 311-31.
} 
to migrate outside of its provisions. ${ }^{31}$ HS Crosthwaite, the Governor of the United Provinces, and Narayan Malhar Joshi, a labour leader and founder of the All-India Trade Union Congress, opposed the Bill's prohibition on emigration for unskilled work and its harsh penalization of those who disregarded its regulations. Both opposed the Bill's restrictions for limiting the mobility of India's working classes and their ability to seek better conditions elsewhere when they were unable to do so in India. Joshi contended that the mobility of all Indians, including labourers, must be maintained because he, like many Indian liberals, thought British India's self-government and improved mobility within empire was imminent after the war. Considering this possibility, he argued that restricting the mobility of unskilled Indian workers seemed contradictory. He insisted that the Government of India focus instead on providing support to labourers fighting against inequality wherever they were situated locally. ${ }^{32}$

Joshi also accused Indian capitalists and landlords in the House for using emigration restrictions to build a pool of cheap labour within India. ${ }^{33}$ Radhika Singha's study on the rise of the Indian passport recognizes that "both the colonial regime and the Indian intelligentsia conceived of the passport for different reasons," and that Indian elites were also invested in developing border controls. In this study, she also notes how debates surrounding the Indian Emigration Act of 1922 framed labour as a commodity that a newly emerging and solidifying Indian nation had ownership over, and which Indian leadership had a stake in managing and controlling for the Indian nation's benefit. ${ }^{34}$

Indian members disagreed on the extent to which unskilled labour emigration to areas surrounding the Bay of Bengal should be regulated. The exclusion of the Straits Settlement Colonies, Federated Malay States, and Ceylon from the Indian Emigration Bill's restrictions meant that it would not do what it claimed: clean up after indenture by ceasing unskilled labour emigration. Indenture was not a primary mover in the eastern Indian Ocean, where 90\% of all Indian migration between 1843 and 1940 took place. Kangani and maistry labour recruitment and circulation systems predated and outlasted indenture in these areas. ${ }^{35}$ For precisely these reasons, Member Bayya N. Sarma, Moderate Congressman, insisted that the Bill should restrict emigration to Ceylon,

\footnotetext{
${ }^{31}$ Government of India, Paper No. II. “Opinions on the Indian Emigration Bill, Opinions Nos 8-11.” 1921, 4, IOR: $\mathrm{L} / \mathrm{PJ} / 6 / 1744$ file 2396

${ }^{32}$ Narayan Malhar Joshi, Excerpt from ILAD, 2198, 6 Feb. 1922, in IOR: L/PJ/6/1744 file 2396.

${ }^{33}$ Ibid..

${ }^{34}$ Singha, "The Great War and a 'Proper' Passport," 289-315.

${ }^{35}$ Ibid.; Sunil S. Amrith, Crossing the Bay of Bengal: The furies of nature and the fortunes of migrants (Cambridge, Mass: Harvard University Press, 2013), 112-3, 141, 184; Sunil S. Amrith, "Tamil diasporas across the Bay of Bengal," American Historical Review, 114, 3 (2009), 547-72.
} 
Malaya, and the Straits Settlements Colonies. ${ }^{36}$ In the Council of State Debates, Ahmedthamby Maricair, who served on the Madras Legislative Council, argued that Indian labourers needed to circulate around the Bay of Bengal, claiming that they faced a lack of sufficient work in India. ${ }^{37}$ Maricair's view aligned with those of planters and colonial officials in Britain's Indian Ocean colonies who insisted that India was overpopulated and needed emigration for famine relief. ${ }^{38}$

The Indian Emigration Bill passed into the Indian Emigration Act of 1922 on 23 February. During the 1920s, white settler governments colluded with the governments of sugar-producing British colonies whose planters desired unfettered access to labourers. Proposals for "Indian colonization schemes" became a means to assuage the push among Indians globally for greater mobility rights in the British empire in light of their contributions to the British war effort. ${ }^{39}$ Indian colonization schemes were settlement schemes incentivized through small land grants. ${ }^{40}$ They were meant to move Indian workers to planters in an organized way under the guise of free migration, keeping wages low, and plantations profitable. ${ }^{41}$ Considering the growing public discussion over the marginalized place of repatriates taking shape after the abolition of indenture in 1917, Gandhi wrote in favour of organized migration schemes that placed Indian repatriates in other colonies that wanted access to a constant stream of Indian labourers. A rise in food prices, influenza outbreaks, and more competitive wages in other industries, coupled with the abolition of Indian indenture drew workers away from sugar estates. ${ }^{42}$

During these years, Gandhi wrote in support of relocating repatriates even though many formerly indentured communities faced violence and suppression in the colonies where they carried out strikes and protests in the face of sharp wage cuts during post-war jumps in the cost of living. ${ }^{43}$ For example, by 1920 , all remaining indenture contracts in

\footnotetext{
${ }^{36}$ BN Sarma, Extract from the CSD, 892, 23 Feb. 1922, IOR: L/PJ/6/1744 file 2396.

${ }^{37}$ Ahmedthamby Maricair, Extract from CSD, 892, 23 Feb. 1922, IOR: L/PJ/6/1744 file 2396.

${ }^{38}$ Amrith, Bay of Bengal, 110; Mike Davis, Late Victorian Holocausts: El niño famines and the making of the third world (London: Verso Books, 2002).

${ }^{39}$ Faisal Devji, Muslim Zion: Pakistan as a political idea (Cambridge, Mass: Harvard University Press, 2013); Robert J. Blyth, The Empire of the Raj: India, eastern Africa and the Middle East, 1858-1947 (New York: Palgrave Macmillan, 2003); Susan Pedersen, The Guardians: The League of Nations and the crisis of empire (Oxford: Oxford University Press, 2015).

${ }^{40}$ W.M. Rotha, General Manager of the Colonial Sugar Refining Company Limited, Fiji, to the Honourable Colonial Secretary, Fiji, 9 Sep. 1922, IOR: L/3/7/1212 file 655; Seecharan, Mother India's Shadow; Mangru, Indenture and Abolition.

${ }^{41}$ See: "Report of the Indian Colonization Enquiry Committee, 1933-1934," 4, in National Archives of South Africa (hereafter: NASA) SAB BNS_1/1/358_119/74_3. See also: National Archives of India (hereafter: NAI) External. South Africa Papers. South Africa Serial No. 1, CC/45-O.R./33-34 File No. 51 Part II.

${ }^{42}$ Mangru, Indenture and Abolition, esp. Ch. 6, 7.

${ }^{43}$ Sannyasi and Chaturvedi, Report on the Emigrants, 9-10.
} 
Fiji were cancelled, and costs of living had increased $86 \%$ since before the war. Fiji imported almost all the staple foods that Indians consumed from Australia and India. Prolonged shipping strikes in Australia combined with a prohibition in India on the export of rice in 1919 substantially raised the cost of living. Furthermore, wages for Indians in Fiji were close to bare subsistence levels. Strikes broke out across the country when the Governor of Fiji dismissed demands to increase the minimum wage to 5 shillings per day, the extension of the franchise to Indians, better educational provisions for Indians, better pay for Indian skilled workers, and the ability to buy land previously barred to Indians. Instead, the Governor called on the Australian and New Zealand Governments for armed troops to support him in suppressing the strikers, and subsequently accused the strikers of escalating the situation. In response to the violent suppression of Indian strikes in Fiji, which he likened to the 1919 massacre in Amritsar, M. K. Gandhi urged the repatriation of Indians from Fiji. Approximately $16 \%$ of Fiji's Indian population registered to repatriate after the 1920 strike. $^{44}$

Post-indenture, many stakeholders in the global dispersion of Indians debated who should be allowed to leave British India's shores and where Indian labourers should be allowed to work. Colonies that no longer had access to an unlimited stream of indentured workers contorted themselves to find new ways to attract "free" Indian labourers. White settler colonies around the Indian Ocean littoral and beyond searched for new ways to manage and reduce Indian numbers. Those who profited from non-indentured Indian labour streams in the eastern Indian Ocean wanted to maintain circulating flows of Indian workers under the guise of effacing the image of Indians as labourers beyond the Indian Ocean. However, stakeholders in these conversations, including Indian nationalists, Indian activists overseas, and other authorities on Indian migration debated the merits of policies that attempted to manage Indian migration circuits.

\section{Disagreeing Over Repatriation}

Established and marginalized advocates for Indians overseas were critical of legislation that appeased white settlers and catered to planter demands for Indian labour postindenture. Some of the most established voices about Indians overseas elevated repatriation to India over remaining in places with anti-Indian legislation. In contrast, less recognized voices raised alarm about the marginalization of repatriates in India. Criticism

\footnotetext{
${ }^{44}$ Ken L. Gillion, The Fiji Indians: Challenge to European dominance, 1920-1946 (Canberra: Australian National University Press, 1977), Ch. 2.
} 
of the repatriation schemes was contentious because it ruptured the assumption that territorial India's departure from British imperialism could inherently protect Indians overseas from white supremacist legislation. The repatriation debates challenged assumptions about the inherence of Indian nationalism that surfaced as part of the transitions of late colonial rule. Repatriation debates also challenged the assumption that a greater sense of national solidarity and "legitimate" national aspirations needed to precede a gradual and orderly British withdrawal. Repatriates who struggled upon arrival in their purported homeland challenged claims of diasporic belonging within India, revealing cracks in universalist iterations of the "project" of Indian diaspora and Indian nationalism. ${ }^{45}$ Qualification and readiness for self-government were staked on claims that expressions of Indian nationalist solidarity were legitimate. ${ }^{46}$

Until the 1930s, the most vocal commentators on the position of Indians overseas argued that repatriation to India was the most desirable alternative to remaining in colonies with anti-Indian legislation. Andrews, an Anglican missionary and friend of Gandhi, independently investigated and reported on overseas Indians. Lesser-known figures who raised alarm about incentivized repatriation schemes, particularly Bhawani Dayal Sannyasi and Benarsidas Chaturvedi, worked to establish themselves as credible voices on Indians overseas, even as Andrews, Gandhi, and others publicly supported ineffective new safeguards to repatriation introduced over the 1920s and 1930s.

Sannyasi's criticism of organized and incentivized repatriation schemes drew from his own struggles with repatriation and reintegration in his father's village community. This experience led him to spend the rest of his life travelling between India and South Africa, keeping in close contact with repatriates. In 1904, as a twelve-year-old boy, he returned to India with his father, who had the financial means to build up a comfortable life upon return by becoming the zamindar in the village of Ismaitpur, in Bihar, which neighboured his father's village, Bahuara. Despite this, Sannyasi's own experience with repatriation was unsettling. He referred to life in Bahuara as a "hell," and was, from the outset, determined to return to Natal. The greatest difficulty for Sannyasi and his father was the process of reintegrating socially. As a requirement for his reintegration, the panchayat, or village assembly, insisted that his father "undergo penitence" by offering a feast to the entire village and surrounding villages. However, the community was unwilling to accept Bhawani Dayal Sannyasi himself as his father's legitimate son, since

\footnotetext{
${ }^{45}$ Amitava Chowdhury, "The diaspora symptom: The global projection of local identities" in Between Dispersion and Belonging, 95-106.

${ }^{46}$ Zachariah, "Decoding political conventions in late colonial India," 188.
} 
they were unsure whether his mother, who died in the Johannesburg in 1899, was also of the kshatriya caste. The panchayat made his father choose between staying with his children or integrating into the community. ${ }^{47}$

Central to Sannyasi's criticism of repatriation was the way in which it disrupted caste privilege, particularly for upper caste repatriates who sought reintegration into their ancestral villages. Sannyasi considered the panchayat's proposition a great source of insult and indignation because he saw himself as having an "appearance, education, culture, and bearing" above the villagers, thus not meriting any treatment as an outcaste. As with Totaram Sanadhya's own indignation at having to work under a lower caste overseer under indenture, Sannyasi's indignation with his treatment upon return was centred on him not being accorded respect he felt entitled to due to his status as a member of the upper caste Kshatriya community. When his father eventually replied to the village panchayat that he would label his South-African born children as illegitimate in exchange for acceptance into the community, Sannyasi was devastated. In 1912, after his father's death, he returned to South Africa. Although Sannyasi inherited property from his father, he decided to sell it, thereby giving up his "home" in India. He spent the rest of his life fighting for his right to remain in the Union of South Africa. ${ }^{48}$

Sannyasi found an ally in his critiques of repatriation in Benarsidas Chaturvedi. They met for the first time in 1912 in Indore, four years after he and his father departed South Africa, and a few months before he returned to South Africa. At the time, Chaturvedi was a Hindi teacher and writer. A few years before meeting, he publicly denounced Sannyasi who had published a letter in the local press criticizing Gandhi for voluntarily offering South African authorities to fingerprint him. It was only after Gandhi advised Chaturvedi that Sannyasi's "intentions ought not to be doubted" that Chaturvedi then wrote him an apology. They also shared an interest in the propagation of Hindi as a unifying language across India and the global Indian diaspora. ${ }^{49}$ Their working relationship and collaborative activism grew when they met in India again in 1925 while Sannyasi was part of the South African Indian Congress (SAIC) delegation to the Government of India. In his autobiography, Sannyasi reflected on how both he and Chaturvedi continued their activism in support of Indians overseas despite the financial precarity they faced. ${ }^{50}$

\footnotetext{
${ }^{47}$ Sannyasi, Autobiography, 75-8.

${ }^{48}$ Ibid., Ch. 6-9.

${ }^{49}$ Ibid., 253-6.

${ }^{50}$ Ibid., 333.
} 
Although Chaturvedi was a little-known figure when he first met Sannyasi in 1912, he became well-known two years later after he supported Fiji repatriate Totaram Sanadhya to publish his memoires of indenture. Historian Mrinalini Sinha's research into the publication history and impact of Sanadhya's memoires reveals Chaturvedi's collaborative literary activism in support of Indians overseas. After they met in June 1915, Chaturvedi invited Sanadhya to spend 15 days with him recounting stories from his life in Fiji. Chaturvedi chose to remain anonymous about his collaboration with Sanadhya until the fourth edition of the book was published in 1973 because he worried that it would have jeopardized his job as a teacher at a government school at the time. ${ }^{51}$

By the early 1920s, Chaturvedi's correspondence and writings revealed his interest in lobbying Indian nationalists and organizations, such as the Indian Imperial Citizenship Association in Bombay, to actively partake in concrete actions assisting Indians overseas. This included raising awareness about the experiences of Indians overseas within India and calling for more concerted transnational programs of advocacy. He was committed to maintaining strong ties between territorial India and overseas Indians by fostering a global national consciousness and unity that included indentured diasporas and their descendants. ${ }^{52}$ Chaturvedi also corresponded with officials deputed by the Government of India to advocate for Indians overseas. His detailed and informative letters can be found in the private papers of P.K. Pillai, a member of a Government of India deputation to investigate the possibility of reviving an Indian migration scheme to British Guiana in 1922. In these letters, Chaturvedi warned Pillai of the exploitative conditions facing Indian labourers in British Guiana, detailing the Government's suppression and imprisonment of Indians striking to protest insufficient wages. ${ }^{53}$

Chaturvedi considered India's "moral and material" support necessary to the struggle against anti-Indian legislation and propaganda in British colonies. This support included facilities and infrastructure allowing Indians overseas to regularly send news and

\footnotetext{
${ }^{51}$ Mrinalini Sinha, "Totaram Sanadhya's Fiji Mein Mere Ekkis Varsh: A history of empire and nation in a minor key” in Ten Books that Shaped the British Empire. Creating the imperial common, eds. Antoinette Burton and Isabel Hofmeyr (Durham: Duke University Press, 2014), 168-89.

${ }^{52}$ Chaturvedi contributed four articles to the Modern Review in 1932, all under the title of "Greater India," in which he outlined a program of developing an institutional hub whose sole purpose was to foster a sense of unity between territorial India and globally dispersed Indians. Chaturvedi to Sastri, 6 Oct. 1922, in Nehru Memorial Museum and Library (Henceforth NMML) Manuscripts: VS Srinivasa Sastri Installment II, Correspondence with Benarsidas Chaturvedi.

${ }^{53}$ Chaturvedi to Pillai, 16 Oct. 1922, in NMML Manuscripts: Dewan Bahadur Kesava Pillai Papers, Correspondence from Benarsidas Chaturvedi.
} 
propaganda for their causes to India for distribution in different Indian vernaculars. ${ }^{54} \mathrm{He}$ found it especially troubling when Indian organizations abroad, such as the SAIC, the Natal Indian Congress, and the East African Indian National Congress, were out of touch with political organizations in India, especially the Indian National Congress. He considered India's "moral and material" support necessary to alleviating discriminatory policies against Indians in British colonies. ${ }^{55} \mathrm{He}$ complained that post-indenture, Indian nationalists' efforts to address the concerns of the Indian diaspora were limited, at best. Beyond the abolition of indenture, he complained that India's "educated men had not followed the poor labourers to the colonies to help them there." He pointed out that Indian organisations and associations had "done very little for these exploited victims of selfish imperialism," and that most Indian leaders had shown "supreme neglect for them and their problems." $" 56$

Both Sannyasi and Chaturvedi agreed that decolonization would better position India to support Indians overseas, yet both were frustrated with their exclusion from the larger program of Indian anticolonialism. Sannyasi wrote that Indian nationalist leaders rarely took the time to "alleviate the immigrants' woes and understand their problems and requirements," resulting in the marginalization of repatriates and the relegation of issues affecting Indians overseas as after-projects of Indian decolonization. ${ }^{57}$ In a speech at the Indians Overseas Conference in 1930, Sannyasi complained that while the Indian National Congress "had been trying to help the cause of Indians overseas, as far as possible,... it had not been able to place the work for Indians abroad on an organized basis." He argued that this work should happen simultaneously. The opinion that issues concerning Indians overseas were a secondary project to the obtainment of Indian decolonization was prevalent in mainstream anticolonial literature. Indian nationalists like Jawaharlal Nehru and Sarojini Naidu generally insisted that the Government of India could not protect Indians overseas until Indians had self-government. ${ }^{58}$

\footnotetext{
${ }^{54}$ Chaturvedi to Sastri, No date, in NMML Manuscripts: VS Srinivasa Sastri Installment II Correspondence with Benarsidas Chaturvedi; Chaturvedi to Sastri, 25 Dec. 1922, in NMML Manuscripts: VS Srinivasa Sastri Installment II Correspondence with Benarsidas Chaturvedi.

55 “Indians Overseas," 29 Aug. 1923, in NMML Manuscripts: VS Srinivasa Sastri Installment II, Correspondence with Benarsidas Chaturvedi.

${ }^{56}$ Ibid.

${ }^{57}$ Sannyasi, Autobiography, 421.

${ }^{58}$ Bhana, Gandhi's Legacy, 35. See also: Jawaharlal Nehru, Selected Works of Jawaharlal Nehru, ed. S. Gopal, (Delhi: B.R. Publishing Corporation, 1974), II: "A foreign policy for India," 13 Sep. 1927; Nehru, Selected Works of Nehru, VIII, 687: "Indians and Sinhalese in Malaya," Statement to the press, Singapore, 2 June 1937 (reprinted in the Hindustan Times, 13 June 1937); Sarojini Naidu, Speeches and Writings of Sarojini Naidu, (Madras: G.A. Natesan \& Co, 1925), III: “Address to East African Congress." Both Nehru and Naidu insisted on Indian and Indigenous shared trusteeship of land.
} 
Chaturvedi and Sannyasi supported M. K. Gandhi's activism, though they often publicly disagreed with him or called upon him to take up more drastic action to support Indians overseas. Initially, Gandhi advocated for mechanisms that allowed for government-supported repatriation for indentured workers and their descendants who were unable to live unindentured in South Africa without being taxed. He expressed dismay at the dispersion of Indian labourers across the British empire to work in exploitative conditions. In a letter to Madras-based journalist, G.A. Natesan, he wrote that labour emigration, either within or outside of British India's borders, had not, as purported by British administrators and planters, reduced poverty within India. ${ }^{59}$ Gandhi primarily saw emigration as resulting in disruption through the departure and repatriation of emigrants, a process which left many vulnerable and alienated both within and outside of British India's borders. ${ }^{60}$ In the late 1920 s, he insisted that repatriates be hastily reexported to the colonies where, as "colonial-born" Indians, they more clearly belonged after they came to learn of the conditions of repatriates in India. ${ }^{61}$

Similarly, Charles Freer Andrews' reports on Indians overseas also advocated for repatriation to rectify indenture. Following Gandhi's return to India in 1915, Andrews continued his work across the globe investigating and reporting on the Indian diaspora across the Indian Ocean and the Caribbean through pamphlet and report publications. ${ }^{62}$ Before 1920, his political pamphlets argued that the extension of self-governing Dominion status to India would eliminate anti-Indian legislation and restrictions on Indian mobility throughout the empire. In 1916, he reported on Indian indentured labourers in Fiji. The report played an important role in the Government of India's decision to abolish indenture in 1917. In 1919 he investigated Indian labourers in Ceylon, as well as Indians in South Africa, Kenya, and Uganda. ${ }^{63}$ He was deeply invested in the idea that a cosmopolitan British world system could provide the framework for fortifying a global human unity under an inclusive iteration of Christianity. However, as he travelled across the empire and saw "exclusion laws" and "insulting regulations" facing Indians in British colonies, he became disillusioned with the possibility of "British Imperialism as a world-ideal." By

\footnotetext{
${ }^{59}$ CWMG Vol. XI, 31 May 1911, “Letter to Ganapathi Agraharam (G.A.) Natesan,” 95.

${ }^{60}$ CWMG Vol. XVII, Before 4 Feb. 1920, in Young India 11 Feb. 1920, “British Guiana and Fiji Deputations,” 8.

${ }^{61}$ See: Mohandas Karamchand Gandhi, "Out of the frying pan," Young India, 9 Sep. 1926, quoted in: Sannyasi and Chaturvedi, Report on the Emigrants, 9.

${ }^{62}$ Hugh Tinker, The Ordeal of Love. C. F. Andrews and India (Oxford: Oxford University Press, 1979).

63 "Biographical Notes," in British Library Manuscripts (Henceforth Mss) Eur D1113.
} 
the 1930s, he changed his position to argue that remaining in the empire would be equivalent to India forfeiting "true independence." 64

Andrews criticized the "Asiatic Question," or white settler fears of Asian encroachment on areas of white settlement. Rather than challenging white supremacist entitlement to settler colonies, he continued to argue that Indians overseas did not pose a threat to white settler supremacy or to other communities in Ceylon and Malaya. Andrews argued that Indians overseas would not encroach on white settler society because they would constantly engage in return migration and their numbers would never expand. In 1920, he argued that Indians had a mythic attachment to Indian soil, and that their eventual repatriation over the years could only be expected. He concluded that, coupled with higher sex ratios of Indian men to women among diaspora communities, especially in exindentured communities, their birth rates would remain low. ${ }^{65}$

Andrews' prolific and widely recognized writings on Indians overseas led the Asiatic Inquiry Commission' (AIC) to consult him in 1920. The purpose of the AIC was to inspect Asian encroachment into areas of white settlement in the Union of South Africa. ${ }^{66}$ After the consultation, Andrews persuaded the Union Government to begin operating the clause in the Indian Relief Act that provided for the incentivized repatriation of Indians. This new program of incentivized repatriation was known as "Voluntary Repatriation." Chaturvedi attributed public support for repatriation programs among prominent Indian nationalists and by the Government of India to Andrews' assumption that Indians overseas could inherently belong in territorial India. While he sympathized with Andrews' desire to alleviate poverty among South African Indian labourers, he took issue with the call for repatriation specifically. Chaturvedi insisted that "Human communities cannot be transplanted and re-transplanted at will." Once Indians had settled in Natal, "to uproot them from their precarious hold upon the new soil was to court disaster." Chaturvedi attributed Andrews' call for repatriation to an "incomplete" and "idealistic" picture of India that starkly differed from the reality facing many repatriates. He explained that while Andrews was well-acquainted with Indian culture and urban life, he fundamentally misunderstood "the rigid village society of Tamil Nad or the United Provinces," claiming that he had "little conception of the difficulties of a man who should return with a wife of an unacceptable caste to a circle where the gap left by his departure

\footnotetext{
${ }^{64}$ Charles Freer Andrews, How India Can Be Free (Madras: Cambridge Press, 1921).

${ }^{65}$ Charles Freer Andrews, The Asiatic Question (Durban: Printed by the Commercial Printing Co, 1920).

${ }^{66}$ Union of South Africa, Report of the Asiatic Inquiry Commission (Cape Town: Cape Times Limited, Government Printers, 1921).
} 
had long been closed." ${ }^{\prime 67}$ According to Chaturvedi, Andrews was, in that moment, partially responsible for both exacerbating anti-Asian sentiment and for mobilizing the voluntary repatriation scheme to target Indians. South African Indians criticized him for this position, arguing that it played into the South African Government legislation that reinforced Indians as temporary settlers. ${ }^{68}$

That same year, Sannyasi also observed Andrews' and Gandhi's support of the Union Government's efforts to operationalize the voluntary repatriation clause in the Indian Relief Act with dismay. Sannyasi was in India at the time that the AIC released its report. His autobiography accused Andrews of relying on a disreputable source of information on repatriation for South African Indians. He claimed that Andrews obtained interviewees for his contribution to the AIC's report from a man named Beni Sigamani, who "collected" a set of Indian workers and "tutored" them to condone repatriation to India as the best resolution to Indian struggles in South Africa. According to Sannyasi, this was why, throughout the 1920s, Andrews endorsed government-managed incentivized repatriation as a relief measure for ex-indentured Indians facing anti-Indian legislation in South Africa. ${ }^{69}$ Sannyasi admitted that although Andrews was "kind hearted," he was misguided, and his reputation as an authority on Indians overseas resulted in the repatriation issue plaguing South African Indian politics for decades to come, as repatriates faced "dire conditions" upon disembarking in India. ${ }^{70}$

Shortly after his endorsement of organized repatriation, Andrews quickly realized its often-harmful effects on repatriates and their families. Chaturvedi recounted Andrews' disillusionment with repatriation in a biography of Andrews he co-authored with Marjorie Sykes. Between May 1920 and July 1921, both Chaturvedi and Andrews were based at poet and Nobel laureate Rabindranath Tagore's school, Santiniketan. Andrews was to look after Santiniketan while Tagore embarked on an international tour. Although they had corresponded since 1917, they met at Santiniketan for the first time in June 1920, after which Andrews asked Chaturvedi to remain with him. Chaturvedi left his post at Chiefs' College at Indore and joined Andrews in supporting new repatriates from British Guiana and Fiji. In 1920, many Indians departed from Fiji as the cost-of-living increased following indenture's abolition. However, many of those repatriates were targeted by

\footnotetext{
${ }^{67}$ Benarsidas Chaturvedi and Marjorie Sykes, Charles Freer Andrew: A narrative (New Delhi: Publications Division, Ministry of Information and Broadcasting, Government of India, 1949), 143-6.

68 Tinker. The Ordeal of Love, 163-4, 187-8, 193-4, 238-9.

${ }^{69}$ Union of South Africa, Report of the Asiatic Inquiry Commission (Cape Town: Cape Times Limited, Government Printers, 1921).

${ }^{70}$ Sannyasi, Autobiography, 266-8.
} 
scammers and thieves upon their arrival or were ostracized in their ancestral villages and drifted back to Matiaburz. More repatriates from Fiji arrived in 1922, when the Colonial Sugar Refining Company cut wages by one third. ${ }^{71}$ Eventually, Andrews founded the Indian Emigrants' Friendly Service Committee, an organisation that met with incoming ships, protecting repatriates from scammers upon their arrival and connecting them with social supports and employment.

Sannyasi criticized Gandhi and Andrews for not seeing "any fault" in incentivized repatriation schemes and continuing to publicly speak in favour of them in 1921 . He witnessed the "despicable" conditions of the repatriates after their arrival in Matiaburj, in Calcutta, where they suffered malarial mosquitos, homelessness, disease, and poverty. Seeing the Matiaburj repatriates deeply disturbed and upset him, yet he continued to read appraisals of the repatriation schemes by Gandhi and Andrews in major Indian newspapers. In response, the agitated Sannyasi approached the Associated Press for the publication of his denouncement of the repatriation schemes. However, the Associated Press refused to accept or broadcast his views. He attributed this to his status of being an "unknown Indian." Sannyasi persisted, approaching the Bharat Mitra, which allowed him to publish his critiques against the repatriation schemes. Before Andrews became aware of the conditions of repatriates in the immediate aftermath of indenture's abolition, Sannyasi vocally denounced the repatriation scheme in both India and Natal and organized labourers in coal mines, tea gardens, factories, and sugarcane plantations to be briefed on the scheme's "ill effects." This eventually attracted the attention of Union Government officials, who were "deeply annoyed" by his activities. One special officer appointed to promote and facilitate the repatriation scheme publicly dismissed Sannyasi as an "irresponsible agitator." Sannyasi was sure that his agitation "broke [the] back," of organized repatriation at least. ${ }^{72}$

Within 5 years of operationalizing the "Voluntary Repatriation" program, dissatisfaction with it among white settlers also began to grow. White settlers in South Africa were adamant that it did not adequately reduce the Indian population in the Union, contain Indian settlement in white-majority areas, or limit perceived "economic competition" with whites. On the other hand, the SAIC and other Indian community organizations criticized the Union Government for using the "Voluntary Repatriation" clause to justify attempts at large scale incentivized emigration of Indians from the Union. The SAIC formed in 1923 and focused on outreach to India as a strategy of resisting anti-

\footnotetext{
${ }^{71}$ Chaturvedi and Sykes, Charles Freer Andrew, 150-1, 183-4.

${ }^{72}$ Sannyasi, Autobiography, 266-8.
} 
Indian legislation. Legislation that Gandhi had initially intended as a means of enabling indentured Indians who faced barriers to repatriation became a means of unsettling Indian claims to settlement and citizenship in South Africa. ${ }^{73}$

In 1925, the SAIC sent a delegation of South African Indians, which included Sannyasi, to the Government of India. The SAIC created the delegation in response to the newly introduced Areas Reservation and Immigration (Further Provision) Bill, which, in combination with Voluntary Repatriation, would intensify economic pressure on Indians to leave the Union. The SAIC delegation called on the Government of India to meet with the Union Government to address anti-Indian legislation. A meeting between the two governments, called the "Cape Town Conference," eventually took place from 17 December 1926 to 12 January 1927, and resulted in the Cape Town Agreement and the Assisted Emigration Scheme of $1927 .^{74}$

Essentially, one euphemistic deportation program replaced another, and the Government of India established an Agency of the Government of India to monitor both the new repatriation scheme and the program of Indian "upliftment" in South Africa for those who chose to remain in South Africa. The Assisted Emigration Scheme provided repatriates a bonus of $£ 20$ and free transportation to India, including transport to whichever area in India they wished to travel to. If repatriates desired, the Government of India agreed to assist them in finding employment and to help them manage their bonus by depositing it in bank accounts upon arrival. Unlike Voluntary Repatriation, the Assisted Emigration Scheme did not require repatriates to give up their right to domicile in South Africa immediately. However, repatriates who took the $£ 20$ bonus, yet later wanted to return to South Africa had to do so within three years, return the bonus, and repay the costs of their transport to the South African Government. ${ }^{75}$

The new repatriation scheme became the source of widespread criticism among South African Indians as it unfolded. However, the SAIC, the Indian delegation to the Cape Town Conference (which included Andrews), and the newly established Agency took the position that the removal of the Areas Reservation and Immigration (Further

\footnotetext{
${ }^{73}$ Proceedings of Conference Between Representatives of The Government of India And Representatives of The Government of South Africa, Cape Town, 17 Dec. 1926, NAI: Ministry of External Affairs. South Africa Section. South Africa Papers, File No. 26-A/H/C/SA/1926. See also: Mesthrie, "Manageable compass," 36-56; Hofmeyr, "Seeking empire finding nation," 153-65; Uma Dhupelia-Mesthrie, Gandhi's Prisoner? The Life of Gandhi's Son Manlial (Cape Town: Kwela Books, 2004), 153-248.

${ }^{74}$ Sannyasi, Autobiography, 320-39. Mesthrie, Gandhi's Prisoner, 169. Uma Shashikant Mesthrie, "From Sastri to Deshmukh: A study of the role of the government of India's representatives in South Africa, 1927 to 1946" (Unpublished PhD diss.: University of Natal, 1987), 39-41.

${ }^{75}$ Cape Town Agreement, 21 Feb. 1927.
} 
Provision) Bill, the updated repatriation terms, and the clause in the Cape Town Agreement that called for a commitment of the South African Government to Indian "upliftment," was a step forward. Gandhi advised his son, Manilal Gandhi, to refrain from amplifying criticism of the new scheme and new Government of India agency in South Africa. ${ }^{76}$ Although Sannyasi was part of the 1925 SAIC delegation that had lobbied the two governments to formulate what would become the Cape Town Agreement, he was among other South African Indians, including members of the Natal Indian Congress, who criticized it in the years following 1927, refusing to cooperate with efforts to reduce their numbers and pushing for the elimination of organized repatriation schemes altogether. ${ }^{77}$ Despite criticism of Assisted Emigration from South African Indians, the newly established Agency representing the Indian Government in South Africa continued to uphold the SAIC as the most reputable group representing Indians in South Africa. ${ }^{78}$

Sannyasi and Chaturvedi's 1927 report refuted the notion that organized repatriation campaigns could ever be preferable to pushing for Indians' rights to continue living where they had settled. ${ }^{79}$ Both pushed Gandhi, Andrews, and other defenders of Assisted Emigration to consider Indian repatriates from South Africa, who ended up displaced upon their return to India. Although the Government of India's agency in South Africa had asked Sannyasi to temper his criticism of the Assisted Emigration scheme in the hopes that it would facilitate white settler cooperation with the terms of the Cape Town Agreement, the dire conditions of Indian repatriates in Matiaburj continued to infuriate and worry him throughout the 1920s-30s. ${ }^{80}$ The Government of India and its Agency in South Africa often amplified only the voices of overseas Indians who were less critical of local colonial governments. ${ }^{81}$

Sannyasi encountered many barriers to speaking out against Assisted Emigration as well. Immediately after the Cape Town Agreement was published, V.S. Srinivasa Sastri, then Agent of the Government of India tasked to oversee the carrying out of the Cape Town Agreement, asked Sannyasi not to speak out against the scheme for two years to avoid giving the impression that the Government of India had violated the Cape Town

\footnotetext{
${ }^{76}$ Mesthrie, Gandhi's Prisoner, 197.

${ }^{77}$ Sannyasi, Autobiography, 337, 348.

${ }^{78}$ Proceedings of Conference between Representatives of the Government of India and Representatives of the Government of South Africa, Cape Town, 15 Jan. 1927, NAI: Ministry of External Affairs, South Africa Section, South Africa Papers, File No. 26-A/H/C/SA/1926; Bhana, Gandhi's Legacy, 35; Mesthrie, "Manageable compass," 36-56; Mesthrie, "From Sastri to Deshmukh"; Anand Cheddie, "The colonial-born and settler's Indian Association and Natal Indian Politics 19331939” (Unpublished Masters' diss.: University of Natal, 1992); Mesthrie, Gandhi's Prisoner, 193-5.

${ }^{79}$ Sannyasi and Chaturvedi, Report on Repatriates from South Africa and All Colonies, 20.

${ }^{80}$ Sannyasi, Autobiography, 348-9.

${ }^{81}$ Mesthrie, "Manageable compass," 36-56; Mesthrie, "From Sastri to Deshmukh."
} 
Agreement's terms. He waited for two years, and then in 1929, traveled to India to investigate the condition of repatriates in the United Provinces, Bihar, Bombay, Bengal, and Madras. He traveled across the country and collaborated with Rai Sahib Kanhiraman Aiyar, a Special Officer appointed by the Government of India for assisting repatriated Indians from South Africa. With the Government of India's help, Aiyar had established the "Natal House," a support house in Madras that cared for repatriates who were disabled or needed additional support. ${ }^{82}$

Sannyasi and Chaturvedi inquired into the wellbeing of repatriates from other British colonies as well. Both were invited by the Government of India and the Government of Bengal to take part in a commission of inquiry to investigate the "Sutlej," a steamer with 600 passengers returning from British Guiana, Trinidad, and Jamaica, upon which 11 died. However, when they were told that they would only be able to begin their investigation after a delay of 4 days, they realized that the ship would have been scheduled to depart for Fiji in one day, and that many of the passengers who disembarked from the ship had already departed to their villages. ${ }^{83}$ Shortly after they drafted their report, Sannyasi was arrested under the Indian Penal Code for rebellion against the Crown and spent just over one year in prison. Subsequent to his imprisonment, Chaturvedi took on the task of publishing the report. Sastri urged Sannyasi not to publish it when it was ready in 1930, to avoid exacerbating tensions surrounding the introduction of the Transvaal Land Tenure Act which would further restrict Indian land ownership and settlement to designated areas. Once Sannyasi was released from Prison in 1931, he and Chaturvedi worked to get the report published. ${ }^{84}$

At times, Sannyasi took ownership of the means he did have to share his views on Indians overseas. In 1922, Sannyasi created and circulated his own publication, which provided information on Indians overseas to a wide readership. ${ }^{85} \mathrm{He}$ claimed that his paper, Hindi, enjoyed global readership and circulation among Indians settled throughout the Union of South Africa, Rhodesia, Mozambique, Tanganyika, Uganda, Kenya, Mauritius, Fiji, Demerara, Trinidad, Jamaica, Grenada, Surinam, Australia, Canada, and

\footnotetext{
${ }^{82}$ Sannyasi, Autobiography, 348-9, 376-80.

${ }^{83}$ Ibid., 379-80.

${ }^{84}$ Ibid., 381, 411-12.

85 The author has been unable to locate copies of Hindi in Indian, South African, or British archives. In its early days, it was a one-man operation, carried entirely by Sannyasi alone. The Amrita Bazar Patrika from 31 Mar. 1922 features an announcement from Sannyasi stating that it is his "desire to render some services to my countrymen residing in the various colonies at present, by way of starting a weekly journal under the name of "The Hindi". I have arranged every thing for its publication and also obtained the Licence[sic] before giving two written security of $£ 100$ each. I have definitely decided to commence the journal from the $1^{\text {st }}$ of May, 1922."
} 
New Zealand. Hindi contained an English language section whose readership included several white South Africans. In his autobiography Sannyasi claimed that it became the "main journal of the Indian immigrants at the time." Contributors to the journal included Andrews, Chaturvedi, Raja Mahendra Pratap, Taraknath Das, Henry Polak, and Sudhindra Bose, who consistently provided articles on issues faced by Indians overseas. It also included special issues with contributions from the Ministers of the Union Government of South Africa, Members of Parliament, and prominent journalists from English language papers. ${ }^{86}$

Criticism of repatriation challenged the notion that Indians overseas inherently belonged in India and that the project of British India's decolonization should precede interventions that helped Indians overseas. Sannyasi and Chaturvedi insisted that India's decolonial project should include Indians overseas, as it was through British imperialism that the global dispersion of Indians happened in the first place. Furthermore, they argued that unless challenges facing Indians overseas were addressed, planters would continue to attempt to acquire Indian labour post-indenture and white settler governments would continue curtailing Indian civil and political rights in the Dominions.

\section{Conclusion}

In the aftermath of indenture, advocates of repatriation who argued for the containment of globally dispersed Indians and their descendants navigated several Indian nationalist imaginaries. Some of these imaginaries justified the continued circulation of Indian labour and capital in the British-controlled eastern Indian Ocean while securing the eased movement of Indian labour and capital beyond this sphere. After the abolition of Indian indenture, repatriation could both make and delegitimize Indian claims to "qualification" for self-government as well as the full mobility, civil, and political rights accorded to white British subjects. The Indian Emigration Act of 1922 made repatriation mandatory and restricted "coolie" migration from going too far beyond British India.

However, the question of what relationship Indians overseas and territorial India grew increasingly ambiguous as the Indian nationalist movement escalated during the 1920s and 1930s. Support for repatriation seemed to cleanly bring closure after the movement for abolition of indenture. However, the policy itself served claims to global Indian nationalist unity and consciousness while ignoring the ways in which being Indian outside of India informed diverse individuals' lived experiences. Sannyasi and Chaturvedi

\footnotetext{
${ }^{86}$ Sannyasi, Autobiography, 275.
} 
denounced the mobilization of repatriation as a strategy for resisting white supremacist legislation and advocated instead for prominent voices and organizations in India to support Indians overseas in more concrete ways that were more closely attuned to their diverse needs. 